\title{
Highly Carboxylate Anion Selective Receptors Containing Trifluoroacetylbenzyl Moieties at the Lower Rim of Calix[4]arene
}

\author{
Seong Sim Whang, Seung Whan Ko, Soo Min Oh, Seongyun Cho, and Kye Chun Nam* \\ Department of Chemistry and the Institute of Basic Sciences, Chomam National Whiversity. Gwangiu 500-757, Korea \\ Anang University Digital Media Depamment. Anvang 708-113. Korea \\ Received December 24, 2002
}

Key Words : Calix[4]arene. Triflıoroacetyl, Carbonate selective receptor

Selective binding of ions is an important aspect of ion detection and ion transport. Due to the difficulties ${ }^{1.2}$ of anion complexation. selective anion receptors are much less explored than that of cations in spite of importance of chemistry and biology. Strong binding with anions was achieved by the positively charged receptors ${ }^{3-6}$ such as ammonium. guanidium. pophỵrin and metal ligands. But several neutral receptors containing urea ${ }^{7}$ and amide ${ }^{8}$ moieties were developed.

Ungaro and coworkers ${ }^{9}$ reported a new type of neutral receptors with perfluorated alcohol function at the upper rim of calix[4]arene and investigated their binding properties which showed a selectivity for carboxylate anion. Previously trifluoroacetophenone derivatives ${ }^{10-12}$ were developed for the carbonate ion selective electrodes. Calix[4]arene lower rim was utilized for the successful ion binding site frequently due to the proper size as well as rigidity. We introduced two trifluoroacetyl benzyl moieties at the lower rim of calix[4]arenes and investigated their binding properties.

Two anion receptors $\mathbf{2 a}$ and $\mathbf{2 b}$ containing $p$-trifluoroacetylbenzyl group at the lower rim of calix[4]arene are obtained in high yield by the reaction of calix[4]arene and $p$ trifluoroacetylbenzyll bromide in the presence of $\mathrm{K}_{2} \mathrm{CO}_{3}$ in $\mathrm{CH}_{3} \mathrm{CN}$. p-Trifluoroacetylbenzyl bromide ${ }^{13}$ was prepared from NBS bromination of $p$-trifluoroacetyltoluene which was obtained by the treatment of toluene with trifluoroacetic anhydride in the presence of $\mathrm{AlCl}_{3}$ in $\mathrm{CH}_{2} \mathrm{Cl}_{2}$. Also two receptors $\mathbf{3 a}$ and $\mathbf{3 b}$ containing $p$-trifluoroacetylbenzoyl group were prepared by the reaction of calix[4]arene and $p$ trifluoroacetylbenzoyl chloride ${ }^{14}$ which was obtained by refluxing $p$-trifluoroacetylbenzoic acid in SOCls. $p$-Trifluoroacetylbenzoic acid can be formed by treating $p$-dibromobenzene with methyl trifluoroacetate in the presence of $n-\mathrm{BuLi}$ at $-78^{\circ} \mathrm{C}$.

The ${ }^{3} \mathrm{H}$ NMR spectrum of $\mathbf{2 a}$ showed the typical characteristics of cone conformation of 1.3-disubstituted

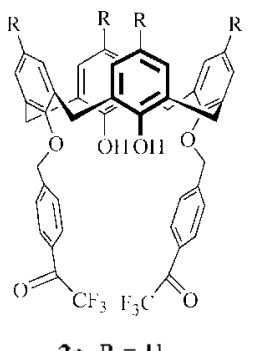
2b. $k-t-B u t y+$

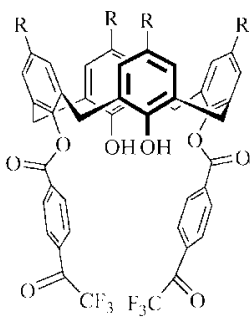

3a, $\mathrm{R}-\mathrm{H}$ 3b, $R-$ t-Butyl derivatives of calix[4]arene such as a pair of doublets at $\delta 4.3$ and 3.5 for the eight bridge methylene protons. two doublets and two triplets at $\delta 6.70 .688 .7 .05$ and 7.17 for the twelve calixarene aromatic protons. a pair of doublets at $\delta 8.05$ and 7.97 for the eight aromatic protons containing $p$-trifluoroacetyl group. a singlet at $\delta 5.24$ for the four benzylic metly lene protons and a singlet $\delta 7.59$ for the two hydroxyl protons. The ${ }^{13} \mathrm{C}$ NMR also confirmed the cone conformation of $2 a$. which showed one bridge methylene carbon peak at $\delta$ 32 and carbonyl carbon peak in trifluoroacetyl group was showed up at $\delta 180$ as a quartet as expected. Ester derivative $3 a$ existed as a cone conformer. but $\mathbf{3 b}$ was found to be a partial cone conformer from the ${ }^{1} \mathrm{H}$ and ${ }^{13} \mathrm{C}$. NMR analysis

The anion coordination properties were investigated from the proton NMR titration in the presence of various anions such as tetrabutylammonium (TBA). fluoride, cluloride. bronide percllorate hỳdrogen sulfate and acetate. Fluoride. clloride bromide perchlorate and hydrogen sulfate were not formed with any complex at all. but acetate was found to form a strong complex. In $\mathrm{CDCl}_{3}$ solution in the presence of acetate both free ligand $\mathbf{2 a}$ and complexed species are observed simultaneously due to the strong complexation. But a fast equilibrium was achieved in DMSO-d solution. A slight downfield shift of a singlet $\mathrm{OH}$ proton resonance at $\delta$ 8.18 and the upfield shift of a pair of doublets at $\delta 8.10$ and 7.88 for the phenyl protons containing trifluoroacetyl group were observed upon addition of the TBA actetate to host 2 a solution. Also the calixarene aromatic protons and benzylic methylene protons were slightly upfield shifted. Chemical shifts were rapidly changed until 1 equivalent of acetate anion was added. But further addition of acetate caused an only negligible chemical shift changes. Any further significant change was not observed after one equivalent of TBA acetate was added. suggesting that 2 a complexed with acetate ion $1: 1$ solution stoichiometry. Relatively large

Table 1. Stability constant ${ }^{u}$ data $\left(\mathrm{K}_{\text {issis }}, \mathrm{M}^{-1}\right)$ of $2 \mathrm{a}, 2 \mathbf{b}, 3 \mathbf{a}$ and $3 \mathbf{b}$ in DMSO-d

\begin{tabular}{ccccccc}
\hline Ligand & $\mathrm{F}^{-b}$ & $\mathrm{Cl}^{-}$ & $\mathrm{Br}^{-}$ & $\mathrm{I}^{-}$ & $\mathrm{CH}_{3} \mathrm{CO}_{2}^{-}$ & $\mathrm{HSO}_{+}^{-}$ \\
\hline $\mathbf{2 a}$ & 0 & 0 & 0 & 0 & 1200 & 0 \\
$\mathbf{2 b}$ & 0 & 0 & 0 & 0 & 5800 & 0 \\
$3 \mathbf{a}$ & 0 & 0 & 0 & 0 & 0 & 0 \\
$3 \mathbf{b}$ & 0 & 0 & 0 & 0 & 0 & 0
\end{tabular}

Errors estimated to be $10^{\circ} \cdot{ }^{b}{ }^{b}$ Tetrabutylammonium salts. 
chemical shift change of the phenyl protons containing trifluoroacetyl groups in the presence of acetate also suggests that acetate ion binds trifluoroacetyl group directly. ${ }^{15}$

The association constants of the various anions to the receptors were obtained from the resulting titration curves using EQ-NMR ${ }^{16}$ and these values are presented in Table 1. A strong selectivity for acetate was observed for the trifluoroacetylbenzyl derivatives of calix[4]arene $\mathbf{2 a}$ and $\mathbf{2 b}$. But the trifluoroacetylbenzoyl derivatives of calix[4]arenes 3a and 3b did not show any indication of binding with anions at all. It was reported that if the geometry were correct, the trifluoroacetylbenzoyl moieties ${ }^{1,11}$ were found to be an excellent binding sites for carbonate anion rather than the trifluoroacetylbenzyl group due to the more electronic deficiency of the carbonyl carbon at the trifluoroacetylbenzoyl moiety. From the energy ninimized 3-D structure of $2 a$ and 3a in Figure 1 it was found that carboncarbon distance of the carbonyl carbon connecting trifluoromethylgroup was $3.63 \AA$ at the benzyl derivative $2 \mathrm{a}$, but $10.12 \AA$ at benzoyl derivative $3 \mathrm{~b}$. Therefore the benzyl derivative 2a provides the proper binding site for the carboxylate anion, on the other hand the benzoyl derivative 3a could not bind with anions due to the long distance between two carbonyl carbons. $t$-Butyl group on the part position of calix[4]arene obviously helps to bind the anion

(a)

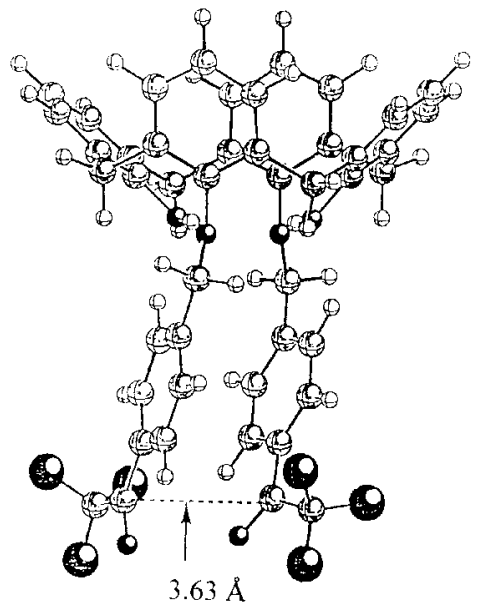

(b)

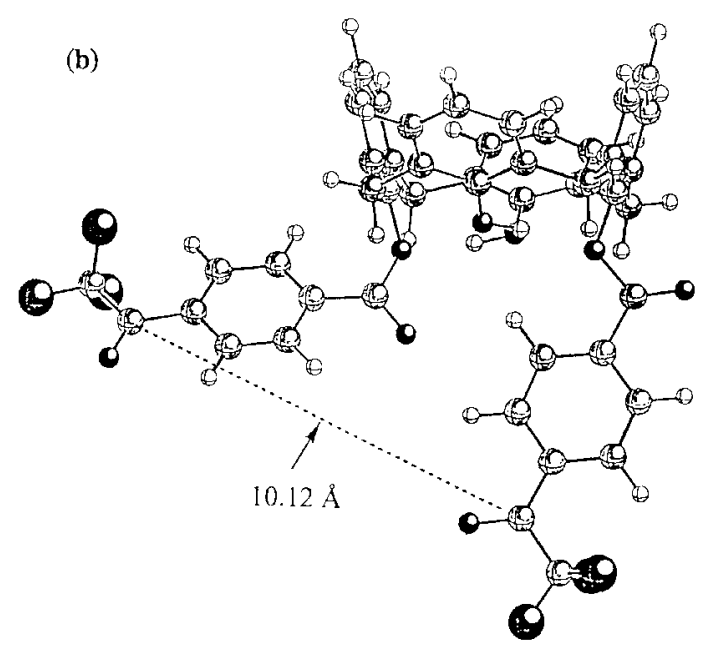

Figure 1. The energy minimized $3-D$ structure of $2 a(a)$ and $3 a(b)$ strongly as reported previously for the ester derivatives of calix[4]arene ${ }^{17}$ which made complexes with alkali metals.

Calix[4]arene lower rim was utilized for the successful ion binding site. We introduced two trifluoroacetyl benzyl moieties at the lower rim of calix[4]arenes and they showed a high selectivity for carboxylate ion over other shepherical halide and hydrogen sulfate ions.

Acknowledgment. This study was financially supported by Chonnam National University in the program. 2001. NMR spectra were taken at the Korea Basic Science Institute Gwangju. Korea.

\section{References and Notes}

1. (a) Dietrich. B. Pure Appl Chem. 1993. 65. 1457. (b) Atwood. J L.; Holman, K. T.: Steed, J. W. Chent Comm. 1996, 1401.

2. Rason. L. Aust. J. Chem 1976, 29, 1635 .

3. (a) Beer, P. D.; Drew; M. G. B.; Hesek. D; Nam. K. C. Chem. Comm 1997. 107. (b) Beer. P. D.: Dent. S. W. Chem Comm 1998. 825

4. Schmidtchen. F. P. J. Ong Chent. 1986. 51.5161

5. Berger. M.: Schmidtchen. F. P. J.An. Chent Soc. 1996. 118. 8947.

6. Jagessar. R. C.: Burns. D. H. Chem. Conm. 1997. 1685

7. (a) Scheerder. J:; Fochi. M.; Engbersen. J. F. L:; Reinhoudt, D. N.d. Org. Chem 1994. 59, 7815. (b) Scheerder, J.; Engbersen. J. F. L.: Castati. A.: Ungaro. R.: Reirhoudt. D. N. J. Ong C/km. 1995. 60.6448.

8. Molzherin. Y.: Rudkevich. D. M.: Verboom. W.: Reinhoudt. D. N. J. Ong Chent 1993. 58.7602.

9. Pelizzi, N.: Casnati, A.: Ungaro, R. Chem. Comm 1998. 2607.

10. Meyerhoff. M. E.: Pretsch. E.: Wetti. D. H.: Simon. W. Anal Chem. $1987,59,144$.

11. Shin. J. H.: Lee. T. S.: Lee. H. J.: Chu. T.: Pyun. H. J.: Nam. H.: Cha. G. S. J. Electroanal Chem 1999. 468.76.

12. Lee. H. T: Yoon. I. T.: Yoo. C. L.: Pyur. H. J.: Cha. G. S.: Nam. H. Anat Chen 2000, 72,4694

13. Campaigne. E; Tullar, B. F. Org. Sy Coll. Vol 4,921.

14. Lehmann. B. Ph.D. Thesis, Swiss Federal Institute of Technology (ETH): Zurich. Switzerland. 1990.

15. Acetate binding site was contirmed by the ${ }^{13} \mathrm{C}$ NMR spectrum. which showed that in the absence of acetate anion carbonyl carbon containing tritluoroacetyl group showed up at $\delta 180$ as a quartet due to the two bond coupling with three fluorine atoms. but this signal was shifted at $\delta 94$ in the presence of acetate ion. indicating that acetate ion binds with trifluoroacetyl group directly.

16. Hynes. M. I. J. Chem. Soc.. Dalton Trums. 1993. 311 .

17. Arnaud-Neu. F.: Collins. E. M.: Deasy. M.: Ferguson1. G.: Harris. S. J : Kaitner. B; Lough. A. J ; Mckervey, M. A.: Marques, E.: Ruhl. B. L.: Schwing-Weill, M. J. Seward, E. M. $J$. Am. Chem. Soc. $1989,111,8681$

18. Some representative data for $2 \mathbf{a} .2 \mathbf{b} .3 \mathbf{a}$ and $\mathbf{3 b}$ are as follows. $2 \mathbf{a}$ : mp 2I0-213 ${ }^{\circ} \mathrm{C}:{ }^{1} \mathrm{H}$ NMR $(\mathrm{CD}, \mathrm{CN}) \delta 8.49$ and 7.96 (two d. $8 \mathrm{H}$. ArH with $\mathrm{CF}_{3} \mathrm{CO} . J=8.3 \mathrm{~Hz}$ ). 8.00 (s. $\left.2 \mathrm{H} . \mathrm{OH}\right) .7 .17$ (d. $4 \mathrm{H}$. ArH. $J=7.4 \mathrm{~Hz}), 7.05(\mathrm{~d}, 4 \mathrm{H}, \mathrm{ArH}, J=7.6 \mathrm{~Hz}), 6.88(\mathrm{t}, 2 \mathrm{H}, \mathrm{ArH}$. $J=7.4 \mathrm{~Hz}) .6 .71\left(\mathrm{t}, 2 \mathrm{H} . \mathrm{ArH}_{,} J=7.6 \mathrm{~Hz}\right) .5 .24\left(\mathrm{~s}, 4 \mathrm{H} .-\mathrm{OCH}_{2^{-}}\right)$. 4.30 and 3.49 (a pair of $\mathrm{d}_{3} 8 \mathrm{H}_{2} \mathrm{ArCH}_{2} \mathrm{Ar}_{3} J=13.2 \mathrm{~Hz}$ ). ${ }^{13} \mathrm{C} \mathrm{NMR}$ $\left(\mathrm{CDCl}_{3}\right) \delta 179.89$ (q. $\left.-\mathrm{CO}-. J=139.5 \mathrm{~Hz}\right) .153 .11 .151 .61 .144 .86$ 132.85. 130.56. 129.31. 128.71. 127.71. 127.09. 125.91 119.40(Ar). 116.62 (q. $\left.-\mathrm{CF}_{3} . J=1120 \mathrm{~Hz}\right) .77 .08\left(-\mathrm{OCH}_{2}\right)$ ). $31.42(\mathrm{ArCH} \mathrm{Ar})$. 2b: $\mathrm{mp} 205-210^{\circ} \mathrm{C}:{ }^{1} \mathrm{H}$ NMR $\left(\mathrm{CD}_{3} \mathrm{CN}\right) \delta 8.01$ and 7.94 (two $\mathrm{d}$. $8 \mathrm{H}$. ArH with $\mathrm{CF}_{3} \mathrm{CO} . J=8.6 \mathrm{~Hz}$ ), 7.18 (s. $2 \mathrm{H} . \mathrm{OH}$ ). 7.08 and 6.82 (two s. $8 \mathrm{H} . \mathrm{ArH}$ ), $5.18\left(\mathrm{~s}, 4 \mathrm{H},-\mathrm{OCH}_{2}\right.$ ). 4.26 and 3.34 (a pair of d. $8 \mathrm{H} . \mathrm{ArCH}_{2}$ Ar. $J=13.2 \mathrm{~Hz}$ ). 1.29 and 0.95 (two s. $18 \mathrm{H}$. tbutyl). ${ }^{13} \mathrm{C} \mathrm{NMR}(\mathrm{CDCl}) \delta 178.93$ (q. $-\mathrm{CO}-. j=141.0 \mathrm{~Hz}$ ). 149.44 . 148.36. 146.58. 144.33. 140.44. 131.29. 129.47. 128.26. 126.29. $126.00,125.73$, and $124.13(\mathrm{Ar}) .115 .57\left(\mathrm{q} .-\mathrm{CF}_{3 .} J=1160 \mathrm{~Hz}\right)$. $77.29\left(-\mathrm{OCH}_{2}-\right), 31.22\left(\mathrm{ArCH}_{2} \mathrm{Ar}\right), 33.86$ and 24.46 (-butyl) 